\title{
Treatment of Intertrochanteric Femur Fractures in the Elderly via Bipolar Hip Arthroplasty or Proximal Femoral Nail
}

\author{
(1) Özgür Korkmaz, (1) Yıldıray Genç
}

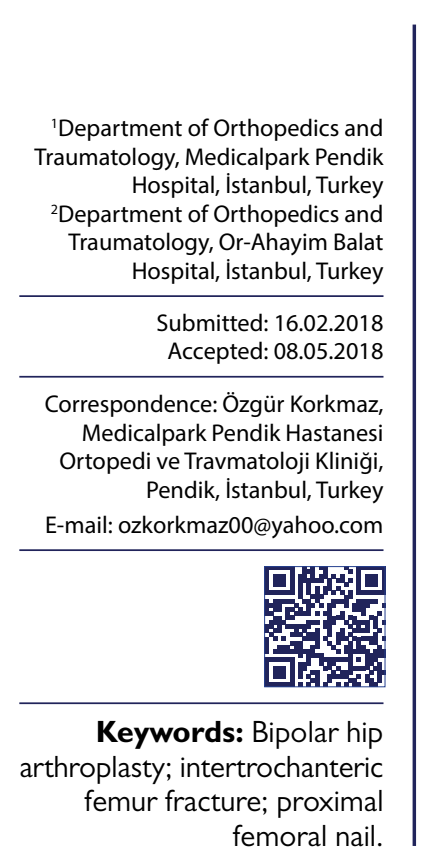

\begin{abstract}
Objective: There is a debate about the treatment of intertrochanteric femur fractures in the geriatric population. A proximal femoral nail (PFN), a sliding hip screw, and bipolar hip arthroplasty (BHA) are the most commonly used treatment modalities. The aim of this study was to compare the blood transfusion rate, duration of surgery, and clinical scores of elderly patients treated with cementless BHA and a PFN.
\end{abstract}

Methods: A total of 38 patients with intertrochanteric femur fractures treated with cementless BHA or a PFN between 2012-2016 were evaluated. In all, 20 patients had surgical treatment with cementless BHA and 18 had surgical treatment with a PFN. All of the patients were evaluated with the Harris Hip Score (HHS) at the last control visit. Blood transfusion rates and the duration of surgery were recorded and the values of both groups were compared statistically.

Results: The mean HHS was $81.4 \pm 10.5$ for the BHA group and $83.7 \pm 13$ for the PFN group. The mean blood transfusion volume was $1.45 \pm 0.6$ units for the BHA group and $0.33 \pm 0.48$ units for the group treated with a PFN. The mean duration of surgery for the BHA group was $95 \pm 23.1$ minutes. In the PFN group, the mean duration of the surgery was $61.8 \pm 7.3$ minutes.

Conclusion: There was a significant difference in the duration of surgery and the blood transfusion volume. The PFN procedure takes less time than $\mathrm{BHA}$, and the blood transfusion volume is smaller. For these reasons, PFN seems to be a better option than BHA.

\section{INTRODUCTION}

Injuries that result from falls are the most common cause of hospital admission in the geriatric population. ${ }^{\left[{ }^{[l]}\right.}$ Intertrochanteric femur fractures account for $45 \%$ to $50 \%$ of fractures around the hip joint in elderly patients. ${ }^{[2,3]}$ Although surgical treatment of intertrochanteric femur fractures remains debatable, particularly regarding the choice of implant for fixation, the sliding hip screw is considered the gold standard for fixation of such fractures. Bipolar hip arthroplasty (BHA) is another commonly used fixation modality for intertrochanteric femoral fractures.

The proximal femoral nail (PFN) was designed to treat trochanteric and subtrochanteric femur fractures, and new-generation PFN provides stable fixation. The intramedullary device offers more stability with a shorter lever arm, shares more loading force, and has a low likelihood of collapse after fixation of intertrochanteric femoral fractures. ${ }^{[4]}$ However, complications such as migration of proximal screws and perforation of the femoral head, varus collapse, and cut-outs and fractures around the femoral nail have been observed after fixation of intertrochanteric femur fractures with PFN. ${ }^{[5,6]}$

Prosthetic replacement is recommended for unstable intertrochanteric fractures because of the complications that may occur after internal fixation. ${ }^{[7-9]}$ Unstable intertrochanteric femur fractures are defined as comminution of the posteromedial buttress with a simple fragment 
or extension of the fracture to the subtrochanteric region. ${ }^{[10]}$ In elderly patients with intertrochanteric femur fractures, treatment with an endoprosthesis can decrease fracture-associated complications. Early mobilization of patients is another advantage of this treatment modality. [II]

This study aimed to compare the results of intertrochanteric femur fractures in elderly patients treated with PFN and BHA.

\section{MATERIAL AND METHODS}

The study protocol was approved by the hospital ethics committee (study number: 203, 06.11.2017); the study was conducted according to the Declaration of Helsinki. Written informed consent was obtained from each patient.

A total of 38 patients with intertrochanteric femur fractures who were treated with cementless BHA $(n=20)$ or PFN ( $n=18)$ between 2012 and 2016 and who were aged $\geq 65$ years at the time of surgery were retrospectively evaluated (Fig. Ia and b). All of the patients were evaluated using the Harris Hip Score (HHS). ${ }^{[12]}$ Blood transfusion rates and duration of surgery details were also recorded. Patients with multiple trauma, pathological fractures, or coxarthrosis before the fracture were excluded.

All of the patients treated with PFN underwent surgery in the supine position. After reducing the fracture under fluoroscopic control, minimally invasive techniques were used during the nailing procedure. All of the BHA procedures were performed via a posterolateral incision. Cementless femoral stems and trochanteric hook plates were used in all cases.

All of the patients were encouraged to stand up the day after the surgery, and all of the patients were enrolled in a physical therapy program. Postsurgical complications, such as implant failure and superficial or deep infections, were recorded for both groups.

\section{RESULTS}

The overall mean age of the patients was $83.6 \pm 7.4$ years. The mean age was $82.7 \pm 7.3$ years in the BHA group and $84.6 \pm 7.6$ years in the PFN group. The mean follow-up period for all patients was $19.7 \pm 8.0$ months. The mean follow-up period was $24.5 \pm 8.3$ months and $14.3 \pm 2.2$ months in the BHA and PFN groups, respectively. The mean HHS was $82.5 \pm 1 \mathrm{I} .7$ points for the entire study group, $81.4 \pm 10.5$ points in the BHA group, and $83.7 \pm 13.0$ points in the PFN group. In the BHA group, 5 patients had excellent HHS ratings, 7 were good, 6 had a fair score, and 2 had a poor score. In the PFN group, 10 patients had an excellent HHS assessment, 3 had a good score, 3 had a fair score, and 2 patients had a poor score. The mean blood transfusion volume was $0.92 \pm 0.78$ units, I. $45 \pm 0.6$ units, and $0.33 \pm 0.48$ units for all of the patients, the BHA group, and the PFN group, respectively. The overall mean duration of surgery was $79.3 \pm 24.1$ minutes, $95 \pm 23.1$ minutes, and $61.8 \pm 7.3$
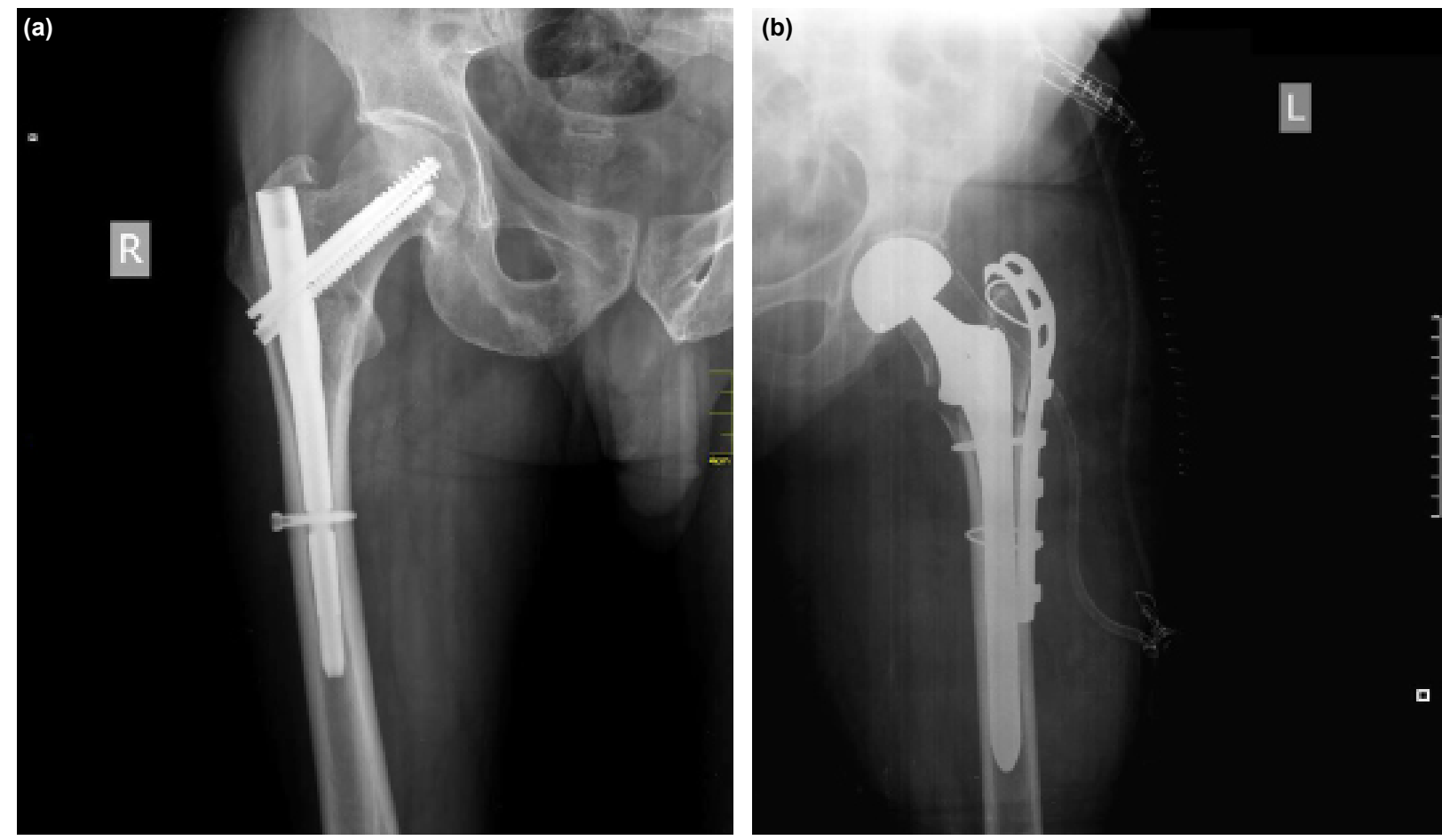

Figure 1. (a) A patient treated with a proximal femoral nail. (b) A patient treated with cementless bipolar hip arthroplasty. 
Table I. Results of both groups

\begin{tabular}{lccccc}
\hline & Mean age & $\begin{array}{c}\text { Mean follow-up } \\
\text { period }\end{array}$ & $\begin{array}{c}\text { Mean Harris } \\
\text { Hip Score }\end{array}$ & $\begin{array}{c}\text { Blood transfusion } \\
\text { rate }\end{array}$ & Surgical time \\
\hline Total & $83.6 \pm 7.4$ years & $19.7 \pm 8.0$ months & $82.5 \pm 11.7$ & $0.92 \pm 0.78$ units & $79.3 \pm 24.1 \mathrm{~min}$ \\
Bipolar hip arthroplasty group & $82.7 \pm 7.3$ years & $24.5 \pm 8.3$ months & $81.4 \pm 10.5$ & $1.45 \pm 0.6$ units & $95 \pm 23.1 \mathrm{~min}$ \\
Proximal femoral nail group & $84.6 \pm 7.6$ years & $14.3 \pm 2.2$ months & $83.7 \pm 13.0$ & $0.33 \pm 0.48$ unit & $61.8 \pm 7.3 \mathrm{~min}$ \\
\hline
\end{tabular}

minutes for the entire study group, the BHA group, and the PFN group, respectively (Table I).

The duration of surgery was statistically significantly different between the 2 groups ( $p \leq 0.05)$; the PFN procedure was shorter than that for BHA. In addition, the blood transfusion rate was statistically significantly different between the groups, with a smaller volume of blood transfusion required in the PFN group compared with the BHA group.

In the BHA group, 2 patients had superficial infections. No other complications, such as deep infection or aseptic failure of the prosthesis, were observed after arthroplasty surgery. In the PFN group, only I patient had a superficial infection, and I patient had an implant failure after 6 months, after which the implant was extracted. The rate of cut-out was $5.5 \%$ in the PFN group.

\section{DISCUSSION}

The union rate is an important issue after fracture fixation. High union rates of up to $100 \%$ have been observed after fixation with intramedullary devices, and union rates of up to $80 \%$ have been reported after fixation with extramedullary devices. ${ }^{[13]}$ Intramedullary devices are load-sharing in small bending moments, and this feature can give the patient early weight-bearing capacity and prevent collapse. In the PFN group, non-union was not observed.

Elderly women with osteoporosis and poor bone quality and who were treated with sliding hip screws and plates or femoral nails after intertrochanteric femur fracture may experience collapse of the fracture and varus displacement. Lag screw cut-out or lateral protrusion is the primary reason for varus collapse of the head and neck after fixation of intertrochanteric femur fractures with PFN and dynamic hip screws. ${ }^{[14,15]}$ The Z-effect and reverse Z-effect are complications that may be observed after treating intertrochanteric femur fractures with PFN. The Z-effect is lateral migration of the inferior screw with varus collapse of the fracture and perforation of the femoral head by the superior screw. The reverse Z-effect is defined as lateral migration of the superior screw and medial migration of the inferior screw. ${ }^{[16]}$ The results of a study that compared PFN with $I$ and 2 lag screws showed that 2 lag screws yielded better results in patients with good bone quality but had a higher cut-out risk in patients with osteoporosis. ${ }^{[17]}$ Uzer et al. ${ }^{[18]}$ compared functional and radiological results as well as complication rates in patients treated with PFN using an integrated, interlocking, compression lag screw and 2 separate lag screws. They found no statistically significant differences in the functional and radiological results or complication rates in the treatment of intertrochanteric femur fractures. In our study, all of the PFN patients were treated with integrated lag screws, and only I cut-out was detected as a complication in this series.

The cut-out rate in patients treated with PFN and dynamic hip screws is approximately $3 \%$ to $10 \% .^{[14,15]}$ In our research, I female patient with osteoporosis had a perforated femoral head at 6 months after reconstruction of the intertrochanteric femur fracture with PFN. Implant extraction was subsequently performed for this patient. The cut-out rate in our study was comparable with that reported in the literature.

As shown in a study by Kumar et al., ${ }^{[19]}$ compared with internal fixation, intertrochanteric femur fractures treated with cemented BHA have the advantage of early ambulation and a shorter hospital stay. ${ }^{\left[{ }^{[9]}\right.}$ In our study, patients in both groups were ambulated the day after surgery. Thus, we do not believe that BHA has an early ambulation advantage. We did not examine the length of the patients' hospital stay after surgery. Kapicioglu et al. ${ }^{[20]}$ assessed hip fractures in extremely elderly patients and reported that patients treated with PFN lived longer than those treated with bipolar cemented hemiarthroplasty. In the current study, mortality rate was not assessed.

In elderly patients, primary cemented BHA for unstable intertrochanteric fractures of the femur has several advantages, such as early ambulation, good functional outcomes, and pain-free hip joint motion. ${ }^{[2]}$ After hip joint reconstruction with BHA, trochanter healing can be a problem. Grimsrud et al. ${ }^{[22]}$ revealed that in 39 patients with unstable 3- and 4-part intertrochanteric hip fractures that were treated with cemented BHA with cerclage fixation of the trochanteric bone fragments, no loosening of femoral components was observed and all of the trochanters healed. Patients who undergo this technique can bear 
weight soon after surgery, and this technique has a low complication rate. Rodop et al. ${ }^{[8]}$ reported that among 37 elderly patients treated with primary BHA for unstable intertrochanteric fractures, 17 (45\%) and 14 (37\%) patients had excellent and good HHS assessments, respectively, at 12 months after surgery. In our study, we performed cementless BHA with trochanteric hook plates, and our clinical results were good with regard to the HHS with no loosening of femoral components observed in the followup period.

Luo et al. ${ }^{[23]}$ compared 7I patients with intertrochanteric femur fractures who were treated with PFN antirotation and 52 patients who were treated with BHA. They found no significant differences between the 2 groups with regard to orthopedic complications, reoperation rate, surgical duration, or HHS, but found significant differences with respect to intraoperative blood loss, transfusion rate, medical complications, and hospital stay duration. A higher I-year postoperative mortality rate was observed in the BHA group than in the PFN group. Their study results suggested that PFN treatment had advantages over $\mathrm{BHA}$, which is consistent with our study results.

Geiger et al. ${ }^{[2]}$ supported PFN for unstable intertrochanteric femoral fractures and dynamic hip screws for stable fractures. The authors found no significant difference with regard to mortality risk for primary cemented hip arthroplasty compared with other treatment modalities for intertrochanteric femoral fractures. Hip arthroplasty is a treatment option for osteoarthritis and osteoporosis that prevents full-weight bearing in patients with intertrochanteric femoral fractures. None of our patients had osteoarthritis before the surgery.

\section{CONCLUSION}

Compared with PFN, hip arthroplasty can reduce implant-related complications and reoperation rates for intertrochanteric femoral fractures. ${ }^{[25]}$ No revision surgery was performed for the BHA group in this study, but our follow-up period was too short for any strong conclusions regarding the reoperation rate. However, implant extraction was performed for I patient who was treated with PFN.

Compared with $\mathrm{BHA}$, performing PFN required less time, and the blood transfusion volume was lower in the PFN group than in the BHA group. Therefore, PFN appears to be a better option than BHA for surgically treating intertrochanteric femur fractures in elderly patients.

Ethics Committee Approval

Approved by the local ethics committee.

Informed Consent

Retrospective study.
Peer-review

Internally peer-reviewed.

Authorship Contributions

Concept: Ö.K.; Design: Ö.K.; Data collection \&/or processing: Y.G.; Analysis and/or interpretation: Ö.K.; Literature search: Y.G.; Writing: Ö.K.; Critical review: Y.G.

Conflict of Interest

None declared.

\section{REFERENCES}

1. Alexander BH, Rivara FP, Wolfe ME. The cost and frequency of hospitalization for fall-related injuries in older adults. Am J Public Health 1992;82:1020-3. [CrossRef]

2. Zuckerman JD. Hip fracture. N Engl J Med 1996;334:1519-23.

3. Kaplan K, Miyamoto R, Levine BR, Egol KA, Zuckerman JD. Surgical management of hip fractures: an evidence-based review of the literature. II: intertrochanteric fractures. J Am Orthop Surg 2008;16:665-73. [CrossRef]

4. Radford PJ, Needoff M, Webb JK. A prospective randomised comparison of the dynamic hip screw and the gamma locking nail.J Bone Joint Surg 1993;75:789-93. [CrossRef]

5. Tyllianakis M, Panagopoulos A, Papadopoulos A, Papasimos S, Mousafiris K. Treatment of extracapsular hip fractures with the proximal femoral nail (PFN): long term results in 45 patients. Acta Orthop Belg 2004;70:444-54.

6. Rethnam U, Cordell-Smith J, Kumar TM, Simha A. Complex proximal femoral fractures in the elderly managed by reconstruction nailing - complications $\&$ outcomes: a retrospective analysis. J Trauma Manag Outcomes 2007;1:1-7. [CrossRef]

7. Sidhu AS, Singh AP, Singh AP, Singh S. Total hip replacement as primary treatment of unstable intertrochanteric fractures in elderly patients. Int Orthop 2010;34:789-92. [CrossRef]

8. Rodop O, Kiral A, Kaplan H, Akmaz I. Primary bipolar hemiprosthesis for unstable intertrochanteric fractures. Int Orthop 2002;26:2337. [CrossRef]

9. Harwin SF, Stern RE, Kulick RG. Primary Bateman-Leinbach bipolar prosthetic replacement of the hip in the treatment of unstable intertrochanteric fractures in the elderly. Orthopedics 1990;13:11316.

10. Babhulkar SS. Management of trochanteric fractures. Indian J Orthop 2006;40:210-8. [CrossRef]

11. Kesemenli C, Subaşi M, Arslan H, Kirkgöz T, Necmioğlu S. Treatment of intertrochanteric fractures in elderly patients with Leinbach type endoprostheses. Ulus Travma Derg 2001;7:254-7.

12. Harris WH. Traumatic arthritis of the hip after dislocation and acetabular fractures: treatment by mold arthroplasty. An end-result study using a new method of result evaluation. J Bone Joint Surg Am 1969;51:737-55. [CrossRef]

13. Leung KS, So WS, Shen WY, Hui PW. Gamma nails and dynamic hip screws for peritrochanteric fractures. A randomised prospective study in elderly patients. J Bone Joint Surg Br 1992;74:345-51.

14. Parker MJ, Pryor GA. Gamma versus DHS nailing for extracapsular femoral fractures. Meta-analysis of ten randomised trials. Int Orthop 1996;20:163-8. [CrossRef]

15. Schipper IB, Steyerberg EW, Castelein RM, van der Heijden FH, den 
Hoed PT, Kerver AJ, et al. Treatment of unstable trochanteric fractures. Randomised comparison of the gamma nail and the proximal femoral nail. J Bone Joint Surg Br 2004;86:86-94. [CrossRef]

16. Werner-Tutschku W, Lajtai G, Schmiedhuber G, Lang T, Pirkl C, Orthner E. Intra- and perioperative complications in the stabilization of per- and subtrochanteric femoral fractures by means of PFN [Article in German]. Unfallchirurg 2002;105:881-5. [CrossRef]

17. Wang CJ, Brown CJ, Yettram AL, Procter P. Intramedullary femoral nails: one or two lag screws? A preliminary study. Med Eng Phys 2000;22:613-24. [CrossRef]

18. Uzer G, Elmadağ NM, Yıldız F, Bilsel K, Erden T, Toprak H. Comparison of two types of proximal femoral hails in the treatment of intertrochanteric femur fractures. Ulus Travma Acil Cerrahi Derg 2015;21:385-91.

19. Kumar Gn K, Meena S, Kumar N V, S M, Raj Mk V. Bipolar hemiarthroplasty in unstable intertrochanteric fractures in elderly: a prospective study. J Clin Diagn Res 2013;7:1669-71.

20. Kapicioglu M, Ersen A, Saglam Y, Akgul T, Kizilkurt T, Yazicioglu O.
Hip fractures in extremely old patients. J Orthop 2014;11:136-41.

21. Singh S, Shrivastava C, Kumar S. Hemi replacement arthroplasty for unstable inter-trochanteric fractures of femur. J Clin Diagn Res 2014;8:LC01-4. [CrossRef]

22. Grimsrud C, Monzon RJ, Richman J, Ries MD. Cemented hip arthroplasty with a novel cerclage cable technique for unstable intertrochanteric hip fractures. J Arthroplasty 2005;20:337-43.

23. Luo X, He S, Zeng D, Lin L, Li Q. Proximal femoral nail antirotation versus hemiarthroplasty in the treatment of senile intertrochanteric fractures: case report. Int J Surg Case Rep 2017;38:37-42. [CrossRef]

24. Geiger F, Zimmermann-Stenzel M, Heisel C, Lehner B, Daecke $\mathrm{W}$. Trochanteric fractures in the elderly: the influence of primary hip arthroplasty on 1-year mortality. Arch Orthop Trauma Surg 2007;127:959-66. [CrossRef]

25. Nie B, Wu D, Yang Z, Liu Q. Comparison of intramedullary fixation and arthroplasty for the treatment of intertrochanteric hip fractures in the elderly: a meta-analysis. Medicine (Baltimore) 2017;96:e7446.

\section{Yaşlı Hastalarda Intertrokanterik Femur Kırklarının Parsiyel Kalça Protezi ve Proksimal Femoral Çivi Ile Tedavi Sonuçları}

Amaç: Geriatrik yaş grubunda intertrokanterik femur kırıklarının tedavisinde kullanılacak implant ile ilgili tartışmalar devam etmektedir. Proksimal femoral çivi, kayan kalça çivileri ve bipolar kalça protezleri kullanılan tedavi yöntemleridir. Çalışmanın amacı sementsiz bipolar kalça protezi ve proksimal femoral çivi yapılan ileri yaş hastaların kan transfüsyon oranlarının, cerrahi sürelerin ve Harris Kalça Skorlama sistemi ile klinik sonuçlarının karşılaştırılması.

Gereç ve Yöntem: 2012-2016 tarihleri arasında sementsiz bipolar kalça protezi ve proksimal femoral çivi ile tedavi edilen 38 intertrokanterik femur kırı̆̆ı olan hasta geriye dönük olarak değerlendirildi. Yirmi hastaya sementiz bipolar kalça protezi yapıldı 18 hastaya proksimal femoral çivi yapıldı. Bütün hastalar son kontrollerinde Harris Kalça Skorlama sistemi ile değerlendirildi. Kan transfüzyon miktarları ve cerrahi süre belirlendi. Her iki grubun değerleri istatistiksel olarak değerlendirildi.

Bulgular: Ortalama Harris Kalça Skoru bipolar kalça protezi ile tedavi edilen grupta $81.4 \pm 10.5$ proksimal femoral çivi ile tedavi edilen grupta $83.7 \pm 13$ olarak bulundu. Bipolar kalça protezi yapılan grupta ortalama kan transfüzyonu $1.45 \pm 0.6$ ünite, proksimal femoral çivi yapılan grupta $0.33 \pm 0.48$ ünite olarak bulundu. Bipolar kalça protezi yapılan grupta ortalama cerrahi süre $95 \pm 23$.I dakika proksimal femoral çivi yapılan grupta ise $61.8 \pm 7.3$ dakika olarak belirlendi. Cerrahi süre ve kan transfüzyonları arasında istatistiksel anlamlı fark bulundu.

Sonuç: Proksimal femoral çivi ile tedavi süresi ve kan transfüzyonu ihtiyacı bipolar kalça protezine göre düşüktür. Bu sebeplerden dolayı yaşlı hastalarda intertrokanterik femur kırıklarının tedavisinde proksimal femoral çivi bipolar kalça protezinden daha iyi bir tedavi yöntemi olduğu düşünülmüşür.

Anahtar Sözcükler: Bipolar kalça protezi; intertrokanterik femur kırı̆ıı; proksimal femoral çivi. 